\title{
Trophic model of the subtropical headwater stream habitat of Formosan landlocked salmon Oncorhynchus formosanus
}

\author{
Hsing-Juh Lin ${ }^{1,2, *}$, Tsung-Ren Peng ${ }^{3}$, I-Chan Cheng ${ }^{1}$, Liang-Wei Chen ${ }^{3}$, \\ Mei-Hwa Kuo ${ }^{4}$, Chyng-Shyan Tzeng ${ }^{5}$, Shang-Te Tsai ${ }^{6}$, Jeng-Tze Yang ${ }^{4}$, \\ Sheng-Hai Wu ${ }^{1}$, Yuan-Hsun Sun $^{7}$, Shu-Fen $\mathrm{Yu}^{1}$, Shuh-Ji Kao ${ }^{8}$ \\ ${ }^{1}$ Department of Life Sciences, ${ }^{3}$ Department of Soil and Environmental Sciences and ${ }^{4}$ Department of Entomology, \\ National Chung Hsing University, Taichung 402, Taiwan \\ ${ }^{2}$ Biodiversity Research Center and ${ }^{8}$ Research Center for Environmental Changes, Academia Sinica, Taipei 115, Taiwan \\ ${ }^{5}$ Institute of Bioinformatics and Structural Biology, National Tsing Hua University, Hsinchu 300, Taiwan \\ ${ }^{6}$ Department of Environmental Resources Management, TransWorld University, Yunlin 640, Taiwan \\ ${ }^{7}$ Institute of Wildlife Conservation, National Pingtung University of Science and Technology, Pingtung 912, Taiwan
}

\begin{abstract}
Using the Ecopath approach and a network analysis, a mass-balance trophic model was constructed to analyze the structure and energy flows of a high-altitude subtropical headwater stream, Chichiawan Stream, the only habitat of the Critically Endangered Formosan landlocked salmon Oncorhynchus formosanus. Natural abundances of carbon and nitrogen isotopes $\left(\delta^{13} \mathrm{C}\right.$ and $\left.\delta^{15} \mathrm{~N}\right)$ were used as a complementary method to stomach content analysis to trace food sources of consumers in the stream. Riparian $\mathrm{C}_{3}$ plants were the major food source of dominant gatherer and filterer aquatic insects, while diatoms were the major food source of scraper aquatic insects. Lindeman trophic analysis indicated that the flows of detritivory and herbivory were quantitatively equally important as food sources for consumers in the stream, suggesting a close terrestrial-aquatic linkage. The trophic model of Chichiawan Stream comprised 13 compartments and 4 integer trophic levels with the highest trophic level of 3.12 for birds. The pedigree index for the trophic model was 0.71 , indicating a high-quality model. The mixed trophic impacts indicated that the biomass of Formosan salmon was unlikely constrained by food sources or predation pressure by birds. In a comparative analysis with other trophic models of temperate mountain streams, the total consumer biomass and mean trophic transfer efficiency were relatively low in this subtropical mountain stream, which is characterized by high precipitation, steep channels, rapid current velocity, and changing flow regime. To conserve the Formosan salmon, the first priorities are agricultural runoff control and maintaining a well-vegetated riparian zone.
\end{abstract}

KEY WORDS: $\delta^{13} \mathrm{C} \cdot \delta^{15} \mathrm{~N} \cdot$ Chichiawan Stream $\cdot$ Riparian $\mathrm{C}_{3}$ plants $\cdot$ Diatoms $\cdot$ Ecopath Network analysis

Resale or republication not permitted without written consent of the publisher

\section{INTRODUCTION}

Our understanding of tropical/subtropical streams is rather limited because studies of these systems have been restricted to only a few geographic re- gions (Boyero et al. 2009). Further studies on trophic structure and dynamics from all tropical streams are particularly needed (Boyero et al. 2009), as the prevailing notions of trophic structure and energy flow in streams are primarily based on research under- 
taken in temperate regions. Dudgeon et al. (2010) indicated that trophic models for northern temperate streams are inadequate for describing tropical systems. High-altitude tropical streams might be functionally more similar to temperate streams than to their lowland counterparts; however, they might differ from temperate streams because of the more constant conditions of light and temperature in the tropics than in temperate regions.

Chichiawan Stream $\left(24^{\circ} 23^{\prime} \mathrm{N}, 121^{\circ} 18^{\prime} \mathrm{E}\right)$ is a subtropical headwater stream of Tachia River in central Taiwan at an elevation between 1770 and $1900 \mathrm{~m}$ (Fig. 1). This stream is the last refuge of the Taiwanese landlocked salmon Oncorhynchus formosanus, one of the southernmost natural salmon populations in the world (Oshima 1955). Overexploitation and habitat degradation due to agricultural development and dam establishment are thought to have

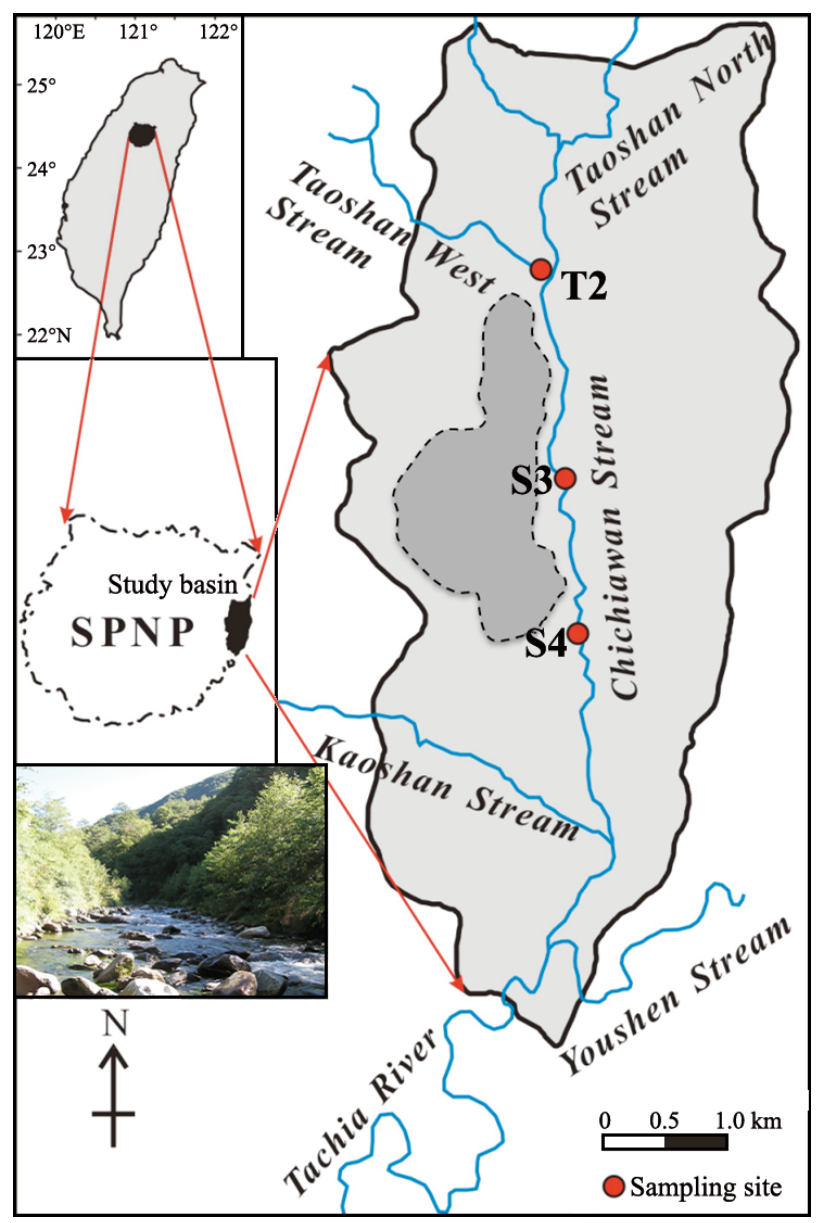

Fig. 1. Locations of the long-term ecological monitoring sites (T2, S3, and S4) and an agricultural area (dark grey) along Chichiawan Stream, Taiwan, and a photograph taken at site S4. SPNP: Shei-Pa National Park resulted in severe decreases in the abundance and distributional area of Formosan salmon after the 1960s (Tsao et al. 1998), and its population size was recently estimated to be only 1000 to 3000 individuals (Chung et al. 2008). This species was listed as Critically Endangered by the IUCN in 1996 (Kottelat 1996). Due to its Critically Endangered status, the abundance of Formosan salmon has been extensively monitored since 1984. Substratum composition, grain size (Chung et al. 2008), and hydrological conditions (e.g. current velocity and water depth, Tsao et al. 1998) were emphasized as important factors in the distribution of this fish. Up to $50 \%$ of the variation in the abundance of Formosan salmon can be explained by physicochemical parameters and substratum composition (Hsu et al. 2010), but the importance of trophic relationships on the abundance of Formosan salmon has received much less attention.

Efforts to conserve and restore stream ecosystems are often hindered by a limited understanding of the dynamics of trophic structure and energy flows (Delong \& Thorp 2006, Hoeinghaus et al. 2007). Stomach content analyses of Formosan salmon have shown that aquatic insects are its main food source (Ueno 1937, Lin et al. 2006), and a potential predator of salmon in Chichiawan Stream is the striated heron Butorides striatus amurensis (Sun 2004). However, it is not known whether food resources and/or predation pressure are limiting factors for the fish population in Chichiawan Stream.

Although stomach contents of Formosan salmon provide a taxonomic resolution of food sources with regard to aquatic insects (Ueno 1937, Lin et al. 2006), different food items consumed may have different digestion rates, which may underestimate the contribution of labile food sources and overestimate the importance of recalcitrant food sources (Hershey \& Peterson 1996). Moreover, stomach contents may only represent the feeding conditions immediately prior to capture rather than being an indicator of long-term average food consumption. Lau et al. (2009) indicated the importance of distinguishing between assimilated and consumed food to obtain a reliable picture of a stream food web. Using stable isotope analysis (SIA) as a complementary method to stomach content analysis, the aims of this study were (1) to determine the food sources fueling Chichiawan Stream, (2) to construct the food web and organic matter flows of this high-altitude subtropical stream, and (3) to use network analysis (Field et al. 1989) to characterize the interconnected flows of organic matter from food sources to top predators in the food web. 


\section{MATERIALS AND METHODS}

\section{Study area}

Chichiawan Stream is a third-order stream located in the Wuling basin of Shei-Pa National Park in subtropical Taiwan (Fig. 1). The stream is $15.3 \mathrm{~km}$ long and 7.1 to $12.3 \mathrm{~m}$ wide, with a high gradient of $13 \%$ and a catchment area of $76 \mathrm{~km}^{2}$ (Lin et al. 1990). The mean forest canopy cover in Chichiawan Stream is $37.3 \%$ (Tsai et al. 2010). The mean water temperature is $12^{\circ} \mathrm{C}$, ranging from $18^{\circ} \mathrm{C}$ in summer to $10^{\circ} \mathrm{C}$ in winter, and mean annual precipitation is $1642 \mathrm{~mm}$, with mean monthly rainfall being generally $<40 \mathrm{~mm}$ in the dry season (October to February), and frequently exceeding $300 \mathrm{~mm}$ during the wet season (May to September; 1981-2010 data from Taichung station, Climatological data annual reports, Taiwan Central Weather Bureau). On average, 3.4 typhoons directly affect this basin every year.

Riffles are the major habitat in Chichiawan Stream and comprise $>80 \%$ of the stream area (Lin et al. 2006). The streambed was primarily created by deposition of weathered sandstone and slate. The mean discharge is 1.84 to $2.30 \mathrm{~m}^{3} \mathrm{~s}^{-1}$ during the dry season and 2.58 to $2.96 \mathrm{~m}^{3} \mathrm{~s}^{-1}$ in the wet season (Chung et al. 2008). Current velocity remains fast year round, averaging $0.33 \mathrm{~m} \mathrm{~s}^{-1}$ in the dry season and $0.49 \mathrm{~m} \mathrm{~s}^{-1}$ in the wet season (Hsu et al. 2010). Consequently, the streambed consists of a high proportion of pebbles $(42 \%)$ in the dry season (winter), but is dominated by rubble $(26 \%)$ and boulders $(21 \%)$ in the wet season (summer) (Lin et al. 2006).

Three long-term monitoring sites have been established along Chichiawan Stream since 2004 (Fig. 1) which cover the main distribution area of the Formosan salmon. Site T2 is located in the upstream reach at an elevation of $1900 \mathrm{~m}$, Site S3 is in the midstream reach at $1790 \mathrm{~m}$, and Site S4 is in the downstream reach at $1742 \mathrm{~m}$. The upper reach of Chichiawan Stream is bordered by riparian forest, but the midstream reach has been developed for agriculture by removing some natural riparian vegetation, including an area of 104 ha of cultivated vegetables and fruit (apples, peaches, pears). The impact of agricultural fertilizer $\left(\mathrm{NO}_{2}{ }^{-}+\mathrm{NO}_{3}{ }^{-}\right)$ inputs on downstream water quality and epilithic algae is significant (Yu \& Lin 2009).

\section{Field sampling and parameter determination}

Samples were collected from all 3 sites from December 2006 to February 2007 (dry season) and during July and August 2007 (wet season) to take account of seasonal changes. All samples and parameters used to construct the model were assembled as much as possible from our own studies (Tables 1 \& 2). Phytoplankton biomass in terms of chlorophyll a (chl a) was determined spectrophotometrically by immediately filtering triplicate water samples through Whatman GF/F filters in the field and then extracting the filters in $90 \%$ acetone for $24 \mathrm{~h}$ at $4^{\circ} \mathrm{C}$ in the dark following the methods of Su et al. (2004). Periphyton biomass was estimated by randomly scraping epilithic biofilm off a surface area of $50 \mathrm{~cm}^{2}$ of rocks ( $\mathrm{n}=$ 9) with a toothbrush and then extracting the chl $a$ in $90 \%$ acetone ( $\mathrm{Yu} \& \mathrm{Lin} 2009$ ). Diatoms were the most dominant taxa of the periphyton communities in the stream and contributed $85 \%$ of the total cell numbers, followed by cyanobacteria and filamentous green algae (Yu \& Lin 2009). Only the C:N molar ratios of periphyton samples which were $<16$ were used for SIA, as these were indicative of diatom-rich

Table 1. Compartments and input parameters for the trophic model of Chichiawan Stream. P/B: production:biomass ratio; Q/B: consumption:biomass ratio; P/Q: production:consumption ratio; UN: unassimilated part of the food; WW: wet weight

\begin{tabular}{|c|c|c|c|c|c|}
\hline Group & $\begin{array}{c}\text { Biomass } \\
\left(\mathrm{g} \mathrm{WW} \mathrm{m}^{-2}\right)\end{array}$ & $\begin{array}{l}\mathrm{P} / \mathrm{B} \\
\left(\mathrm{yr}^{-1}\right)\end{array}$ & $\begin{array}{l}\mathrm{Q} / \mathrm{B} \\
\left(\mathrm{yr}^{-1}\right)\end{array}$ & $\mathrm{P} / \mathrm{Q}$ & UN \\
\hline 1. Phytoplankton & 0.054 & 85.0 & & & \\
\hline 2. Periphyton & 45.94 & 48.0 & & & \\
\hline 3. Shredders & 0.026 & $2.9^{\mathrm{a}, \mathrm{b}}$ & & $0.14^{\mathrm{a}, \mathrm{b}}$ & $0.70^{\mathrm{c}}$ \\
\hline 4. Scrapers & 0.852 & $6.0^{\mathrm{d}, \mathrm{e}}$ & & $0.06^{\mathrm{f}}$ & $0.50^{\mathrm{c}}$ \\
\hline 5. Filterers & 0.089 & $8.4^{\mathrm{e}}$ & & $0.12^{\mathrm{h}}$ & $0.50^{\mathrm{c}}$ \\
\hline 6. Gatherers & 0.212 & $12.7^{\mathrm{f}, \mathrm{i}}$ & & $0.08^{\mathrm{i}}$ & $0.65^{\mathrm{c}}$ \\
\hline 7. Predators & 0.254 & $6.0^{\mathrm{g}}$ & & $0.25^{\mathrm{h}}$ & $0.20^{\mathrm{b}}$ \\
\hline 8. Non-insect grazers & 0.693 & $6.0^{\mathrm{k}}$ & & $0.12^{\mathrm{k}}$ & $0.40^{1, \mathrm{~m}}$ \\
\hline 9. Flatworms & 0.467 & $8.1^{\mathrm{h}}$ & & $0.20^{\mathrm{h}}$ & $0.24^{\mathrm{h}}$ \\
\hline 10. Minnows & 0.118 & $0.7^{\mathrm{n}}$ & $5.6^{\mathrm{n}}$ & & $0.20^{\mathrm{j}}$ \\
\hline 11. Formosan salmon & 1.270 & $1.1^{\mathrm{n}, \mathrm{o}}$ & $4.3^{\mathrm{n}}$ & & $0.20^{\mathrm{j}}$ \\
\hline 12. Birds & 0.015 & $1.3^{p}$ & $46.0^{\mathrm{p}}$ & & $0.20^{j}$ \\
\hline 13. Detritus & 8.839 & & & & \\
\hline \multicolumn{6}{|c|}{ 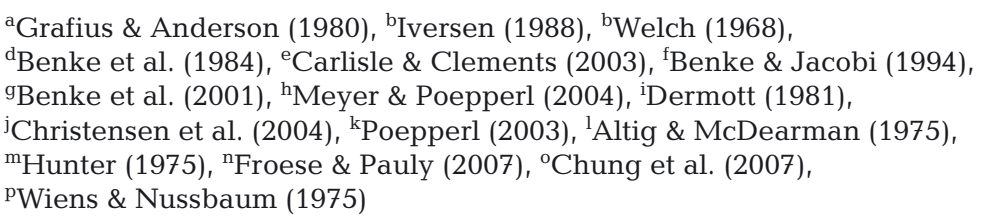 } \\
\hline
\end{tabular}


Table 2. Diet composition matrix assembled from research data and the literature for the construction of the trophic model of Chichiawan Stream. Values represent the proportion by weight of each prey item in the diet

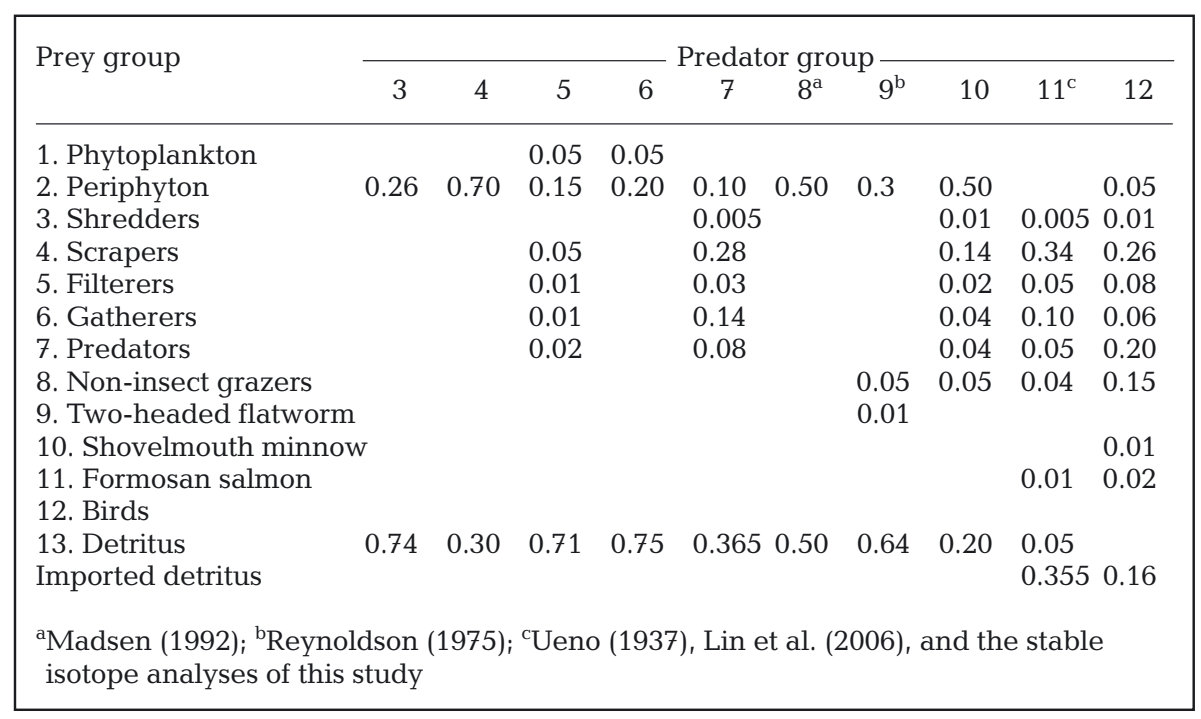

to the P-I curve and surface light data in each season (2006-2007 data from Taichung station, Climatological data annual reports, Taiwan Central Weather Bureau). DO concentrations were monitored with a DO meter (Model 52, YSI). Oxygen production rates were converted to carbon fixation rates using a photosynthetic quotient of 1.2 (Meyercordt \& Meyer-Reil 1999).

Biomasses of aquatic invertebrates were quantified using a Surber sampler (with an area of $30.48 \times$ $30.48 \mathrm{~cm}$ and a mesh size of $250 \mu \mathrm{m})$. Six random samples in riffles were taken at

samples (cf. Frost et al. 2007). Filamentous green algae (Cladophora spp.) for SIA were sampled by hand.

Net production rates of periphyton and phytoplankton were concurrently determined from changes in dissolved oxygen (DO) concentrations in chambers $(10 \mathrm{~cm}$ wide $\times 25 \mathrm{~cm}$ long $\times 15 \mathrm{~cm}$ deep) using stream water only and periphyton+stream water in outdoor flowing water tanks placed in Chichiawan Stream to maintain the temperature at ambient levels following the methods of Lin et al. (2005) at each site in each season. The stream water chamber was used to both determine the production rates of phytoplankton and correct the DO measurements in the periphyton+stream water chamber. To determine periphyton production, randomly selected cobbles (n $=15$, ca. $65 \mathrm{~mm}$ ) with periphyton on them were collected from riffles, and one cobble was put in each chamber. Incubation was conducted around noon (10:00 14:00 h) when irradiance was saturated, and each tank was exposed to different irradiances $(0,30$, 50, 70, and $100 \%$ shading) by interposing screens with different mesh sizes. Three replicate chambers were incubated for each irradiance level. The relationship between net production rates and irradiances (the P-I curve) at each site in each season was described by the equation of Jassby \& Platt (1976) using a nonlinear curve-fitting procedure in the program SigmaPlot 8.0 (SPSS). Annual net production rates of periphyton and phytoplankton were respectively calculated by integrating interpolated net production rates under various irradiances by referring each site in each season. These were carried back to the laboratory to determine the biomass and identify organisms to the lowest possible taxonomic level using available keys (Merritt \& Cummins 1996, Kawai \& Tanida 2005) except for the Chironomidae, which were only classified into Tanypodinae and non-Tanypodinae. Samples for SIA were placed in clean water for $1 \mathrm{~d}$ to allow for gut evacuation.

Fish populations were counted by snorkeling during the daytime between ca. 10:00 and 17:00 h. Counting began at the downstream end at each site (about $300 \mathrm{~m}$ long) and was completed in a single upstream pass. Two trained snorkelers slowly swam upstream parallel to the main channel and counted fish outwards and towards the bank nearest to them to avoid double-counting. Prior to the actual counting, estimating fish lengths was practiced on objects of known length lying on the stream bottom with the help of a ruler for size estimation. Three life stages were classified according to the fish total length (Chung et al. 2007): 5-15 cm for juvenile salmon, $15-25 \mathrm{~cm}$ for subadults, and $>25 \mathrm{~cm}$ for adults. There has been little study on the biology of the other dominant fish species in the stream, the shovelmouth minnow Varicorhinus barbatulu, so classification of minnow size classes was based on the total lengths of Formosan salmon. The total abundance of each size class for both fishes was recorded at each site. Biomass was estimated by the length-weight relationship using an empirical equation of Lan (2005). Samples of Formosan salmon for SIA were collected using a cast net (area $10 \mathrm{~m}^{2}$, mesh size $1 \mathrm{~cm}$ ). 
Point-count observations were conducted to estimate the species and abundance of birds along the stream. Trained observers stood at a fixed point on the shores of the stream at each site for $8 \mathrm{~min}$ and recorded everything they heard and saw with the aid of binoculars during the first $3 \mathrm{~h}$ of daylight. In each season, 3 counts were conducted at each site to overcome varying detectability over time and among species. Biomass was calculated by multiplying the average live weight of a given species taken from Sun (2004) by bird abundance values for that species.

Few studies have been carried out on small aquatic invertebrates in Taiwan, so the production: biomass ratio (P/B), consumption:biomass ratio $(\mathrm{Q} / \mathrm{B})$, production:consumption ratio $(\mathrm{P} / \mathrm{Q})$, and unused consumption (UN) were derived from the literature (Table 1). Estimates of Q/B for fish were computed using an empirical model developed by Palomares \& Pauly (1989). Estimates of P/B for fish were obtained by searching FishBase (Froese \& Pauly 2007). P/B and $Q / B$ values for birds were computed using the empirical model developed by Wiens \& Nussbaum (1975) and Crocker et al. (2002), respectively. UN values of fish and birds were assumed to be $20 \%$ (Christensen et al. 2004).

Senesced or microbe-conditioned leaves from dominant riparian $\mathrm{C}_{3}$ and $\mathrm{C}_{4}$ plants best represent terrestrial detritus in streams (Finlay 2001), and these were picked off the ground by hand for SIA. Dominant $\mathrm{C}_{4}$ plants were Arundo formosana and Miscanthus floridulus. Dominant $\mathrm{C}_{3}$ plants were Alnus formosana, Pinus taiwanensis, Polygonum multiflorum var. hypoleucum, Quercus variabilis, Tetrapanax papyriferus, and Vaccinium bracteatum.

In each season at each site, 3 hoop-nets $(1 \mathrm{~mm}$ mesh, $50 \mathrm{~cm}$ long, with a $25 \times 25 \mathrm{~cm}$ front opening) were firmly placed in the water with the opening completely submerged at $1 / 4,1 / 2$, and $3 / 4$ of the distance from the left bank to collect upstream inputs of coarse particulate organic matter (CPOM). Five aerial or vertical-input traps were hung over the water surface of the stream from nearby trees at each site to collect vertical inputs of CPOM. Three lateral-input traps held by 2 stakes were each installed on the right and left banks at each site to collect inputs of CPOM from the lateral directions. On each sampling occasion, these traps stayed for a $48 \mathrm{~h}$ period. Benthic organic matter (BOM) was also collected from the streambed in triplicate using a square-sided benthic sampler with an area of $0.1 \mathrm{~m}^{2}$ fitted with a $1 \mathrm{~mm}$ mesh hoop-net. Transported organic particles in the stream of $0.45 \mu \mathrm{m}$ to $1 \mathrm{~mm}$ were treated as fine particulate organic matter
(FPOM). To collect FPOM, 21 of water were collected and filtered in triplicate through pre-weighed $0.45 \mu \mathrm{m}$ Millipore filters. All samples were brought back to the laboratory where they were sorted and weighed after drying in an oven at $60^{\circ} \mathrm{C}$ for $24 \mathrm{~h}$. FPOM was determined by subtracting the mass of the inorganic seston from the dry mass after burning in a $450^{\circ} \mathrm{C}$ muffle furnace for $4 \mathrm{~h}$.

Factors used for conversion between chl $a$, carbon, dry weight, and wet weight were based on a table summarized by Opitz (1996). Biomass data were then recorded as the wet weight $(\mathrm{WW}) \mathrm{m}^{-2}$, and flow data were recorded as $\mathrm{WW} \mathrm{m} \mathrm{m}^{-2} \mathrm{yr}^{-1}$.

Diet composition of Formosan salmon was primarily derived from previous stomach content analyses (Ueno 1937, Lin et al. 2006). Stomach or gut contents of shovelmouth minnows, aquatic insects, and tadpoles were sorted taxonomically and counted. Diet composition analysis followed the methods described by Hyslop (1980). SIA was used as a complementary method to stomach content analysis. Few published data are available on the diets of gastropods and flatworms in Taiwan, so this information was obtained by searching the literature (Reynoldson 1975, Madsen 1992). Bird diets were determined by observing the types of prey and examining regurgitated pellets which consist of the indigestible parts of food.

\section{SIA}

For small-sized aquatic insects, multiple individuals from the same taxon were pooled and treated as a single replicate, and the entire body was used for SIA. For large fish, individual specimens were treated as replicates, and only muscle tissues were used for SIA. All samples were rinsed with deionized water. Plant tissues were dried in an oven at $60^{\circ} \mathrm{C}$ for $48 \mathrm{~h}$ and then ground up. Animal tissues were freeze-dried and then ground up. Subsamples (of around $1.0 \mathrm{mg}$ ) of dried tissue were enclosed in tin capsules and analyzed on a continuous-flow isotope ratio mass spectrometer (Thermo Finnigan Delta $^{\text {plus }}$ Advantage) coupled with an elemental analyzer (Carlo-Erba EA 2100). Stable isotope data were reported in standard notation as: $\delta \mathrm{X}(\% \mathrm{o})=$ $1000\left[\left(R_{\text {sample }} / R_{\text {standard }}\right)-1\right]$, where $R={ }^{13} \mathrm{C} /{ }^{12} \mathrm{C}$ or ${ }^{15} \mathrm{~N} /{ }^{14} \mathrm{~N} . \delta^{13} \mathrm{C}$ or $\delta^{15} \mathrm{~N}$ is the \%o deviation of the sample from the international standard, i.e. Pee Dee Belemnite for the $\delta^{13} \mathrm{C}$ analysis and air $\mathrm{N}_{2}$ for the $\delta^{15} \mathrm{~N}$ analysis (Gonfiantini et al. 1995). The precisions of the $\delta^{15} \mathrm{~N}$ and $\delta^{13} \mathrm{C}$ analyses were $<0.15$ and $0.20 \%$, respectively. 


\section{Estimates of food source contributions}

In order to identify the major food sources of a given consumer, we used the dual-isotope, multiplesource mixing model IsoSource (Phillips \& Gregg 2003) in both the dry and wet seasons. Tolerance of IsoSource was set to $0.05 \%$, which is an indication of a feasible solution (Phillips \& Gregg 2003). The tolerance increased to higher values when the isotope values of dominant consumers were outside the polygons enclosing all possible food sources.

Fractionation values of $\delta^{13} \mathrm{C}$ and $\delta^{15} \mathrm{~N}$ between a consumer and its food sources were carefully assessed before employing IsoSource. DeNiro \& Epstein (1978) found that an animal is about $1 \%$ enriched in $\delta^{13} \mathrm{C}$ relative to its diet. Minagawa \& Wada (1984) showed that the mean enrichment in $\delta^{15} \mathrm{~N}$ with a single feeding process is $3.4 \%$. McCutchan et al. (2003) reported that the enrichment of $\delta^{13} \mathrm{C}$ is $1.3 \pm 0.30 \%$ (mean $\pm \mathrm{SE}$ ) and that of $\delta^{15} \mathrm{~N}$ is $2.9 \pm$ $0.32 \%$ for muscle samples, but the enrichment for samples of whole organisms is $0.3 \pm 0.14 \%$ o for $\delta^{13} \mathrm{C}$ and $2.1 \pm 0.21 \%$ o for $\delta^{15} \mathrm{~N}$. Based on the literature and our own observations, we applied trophic enrichment values of $1.0 \% \delta^{13} \mathrm{C}$ and $3.4 \% \delta^{15} \mathrm{~N}$ for each trophic transfer in Formosan salmon for which muscle tissues were analyzed. However, trophic enrichment values of $0.5 \% \quad \delta^{13} \mathrm{C}$ and $2.3 \% \delta^{15} \mathrm{~N}$ were applied to correct for isotopic shifts of smallsized aquatic insects for which the entire body was analyzed (McCutchan et al. 2003). A t-test was used to determine whether $\delta^{13} \mathrm{C}$ and $\delta^{15} \mathrm{~N}$ values of plants, algae, aquatic insects, and Formosan salmon significantly differed between the dry and wet seasons in Chichiawan Stream.

\section{Modeling approach}

A trophic model of Chichiawan Stream was constructed using the Ecopath routine in the Ecopath with Ecosim software system (Christensen et al. 2004) to quantify organic matter flows in the food web. For each compartment $i$, a mass-balance budget can be expressed as:

$$
\mathrm{P}_{i}-\mathrm{B}_{i} \mathrm{M}_{i}-\mathrm{P}_{i} \times\left(1-\mathrm{EE}_{i}\right)-\mathrm{EX}_{i}-\mathrm{AC}_{i}=0
$$

where M2 is predation mortality, EE is ecotrophic efficiency (i.e. the part of the production that is either passed up the trophic level or exported), 1 - EE is 'other mortality,' $\mathrm{EX}_{i}$ is the portion of $i$ exported to other systems, and $\mathrm{AC}_{i}$ is the accumulation of $i$ during the study period.
A predator group $j$ is connected to its prey groups by its consumption. Thus, Eq. (1) can be re-expressed as:

$\mathrm{B}_{i} \times \mathrm{P} / \mathrm{B}_{i} \times \mathrm{EE}_{i}-\Sigma_{j} \mathrm{~B}_{j}-\mathrm{Q} / \mathrm{B}_{j} \times \mathrm{DC}_{j i}-\mathrm{EX}_{i}-\mathrm{AC}_{i}=0$

where $\mathrm{DC}_{j i}$ is the fraction of prey $i$ in the average diet of predator $j$. It was assumed that the food matrix remained stable during the study period.

Consumption of $j$ is then connected to its production, which can be re-expressed as:

$$
\Sigma_{j} \mathrm{~B}_{j} \times \mathrm{Q} / \mathrm{B}_{j}=\mathrm{P}_{j}+\mathrm{R}_{j}+\mathrm{UN}_{j}
$$

where $\mathrm{R}$ is respiration. For further details and algorithms of the Ecopath model structure, see Christensen et al. (2004).

\section{Model compartments}

Major species of aquatic insects with similar sizes and diets in Chichiawan Stream were grouped within the same compartment. Bacterial biomass was included in the compartment of organic detritus as recommended by Christensen et al. (2004). A 13-compartment model for the stream was developed consisting of the following groups: (1) phytoplankton, (2) periphyton (mainly diatoms), (3) shredder aquatic insects (including Nemouridae, Lepidostomatidae, and Sericostomatidae), (4) scraper aquatic insects (Heptagenidae), (5) filterer aquatic insects (including Simuliidae, Hydropsychidae, and Stenopsychidae), (6) gatherer aquatic insects (including Chironomidae, Ephemeridae, and Ephemerellidae), (7) predator aquatic insects (including Perlidae, Rhyacophilidae, and Tipulidae), (8) non-insect grazers (including tadpoles of Bufo bankorensis and Pseudoamolops sauteri and the gastropods Hippeutis sp. and Lymnaea sp.), (9) two-headed flatworm Dugesia japonica, (10) shovelmouth minnow, (11) Formosan salmon, (12) birds (including the Asian dipper Cinclus pallasii and Mandarin duck Aix galericulata), and (13) detritus. Exports of fish and invertebrates due to consumption by forest animals were assumed to be small compared to those within the stream and therefore were not included in the model. The pedigree routine (Funtowicz \& Ravetz 1990) was used to determine an overall index of model 'quality,' based on the origin and quality of each input datum of the model.

\section{Model balancing and verification}

Because Ecopath uses linkages of production of 1 compartment with consumption of other compart- 
ments to calculate 1 missing parameter for each group, the most questionable parameter of each compartment can be treated as an unknown and calculated by Ecopath. In this study, the biomass of each compartment and primary productivity were the most reliable data. EE was treated as an unknown and calculated by Ecopath. Some P/B, Q/B, and DC values of invertebrates were assembled from the literature (Tables $1 \& 2$ ) and were considered to be less reliable in the stream model. Therefore, they were gradually modified during the balancing exercise. Most of the changes were rather small and remained within $20 \%$ of the input value. Verifying the realism of the Ecopath model followed the general methodology described by Christensen et al. (2004).

\section{Network analysis}

Transfer details of organic matter from primary producers and detritus to top predators in the food web can be revealed using network analysis (Field et al. 1989). The mixed trophic impacts (Ulanowicz \& Puccia 1990) were calculated to assess the direct and indirect impacts of a change in the biomass of each compartment on the other compartments. The sum of consumption, exports, respiratory flows, and flows into detritus or the total system throughput (TST) is indexed in terms of how much matter the system processes. The Finn cycling index (FCI) of the cycle analysis (Kay et al. 1989) was used to measure how retentive the stream was. The Lindeman trophic analysis (Kay et al. 1989) summarizes the complicated food web in terms of a single linear food chain. The trophic efficiency of the transfer from one aggregated trophic level to the next can be calculated as the fraction of the input of organic matter to a given level that is transferred to the next higher level.

\section{RESULTS}

\section{Isotopic signatures of basal sources}

$\delta^{13} \mathrm{C}$ values of the 4 major basal sources in Chichiawan Stream showed distinct differences, regardless of season (dry or wet; Table 3). The increasing order of enrichment in $\delta^{13} \mathrm{C}$ values was riparian $\mathrm{C}_{3}$ plants, FPOM, diatoms, filamentous green algae, and riparian $\mathrm{C}_{4}$ plants. No significant seasonal variations in $\delta^{13} \mathrm{C}$ values were found for riparian $\mathrm{C}_{3}$ and $\mathrm{C}_{4}$ plants, diatoms, or filamentous green algae.

$\delta^{15} \mathrm{~N}$ values of diatoms and filamentous green algae were relatively enriched over those of riparian $\mathrm{C}_{3}$ and $\mathrm{C}_{4}$ plants (Table 3 ). No significant seasonal variations in $\delta^{15} \mathrm{~N}$ values were found for riparian $\mathrm{C}_{3}$ or $\mathrm{C}_{4}$ plants. However, $\delta^{15} \mathrm{~N}$ values of diatoms were significantly more enriched in the dry than in the wet season. $\delta^{15} \mathrm{~N}$ values of filamentous green algae tended to be more enriched in the dry season, although the statistical significance could not be determined because there was only a single measurement.

Table $3 . \delta^{13} \mathrm{C}$ and $\delta^{15} \mathrm{~N}$ (mean $\pm 1 \mathrm{SE}$ ) of basal food resources and dominant consumers and C:N molar ratios (mean $\pm 1 \mathrm{SE}$ ) of basal food resources collected from Chichiawan Stream during the dry and wet seasons. The number of replicates (if any) is in parentheses. FPOM: fine particulate organic matter, na: samples unavailable. Asterisks indicate a significant difference between the wet and dry seasons: ${ }^{*} \mathrm{p}<0.05,{ }^{* *} \mathrm{p}<0.05,{ }^{* * *} \mathrm{p}<0.001$

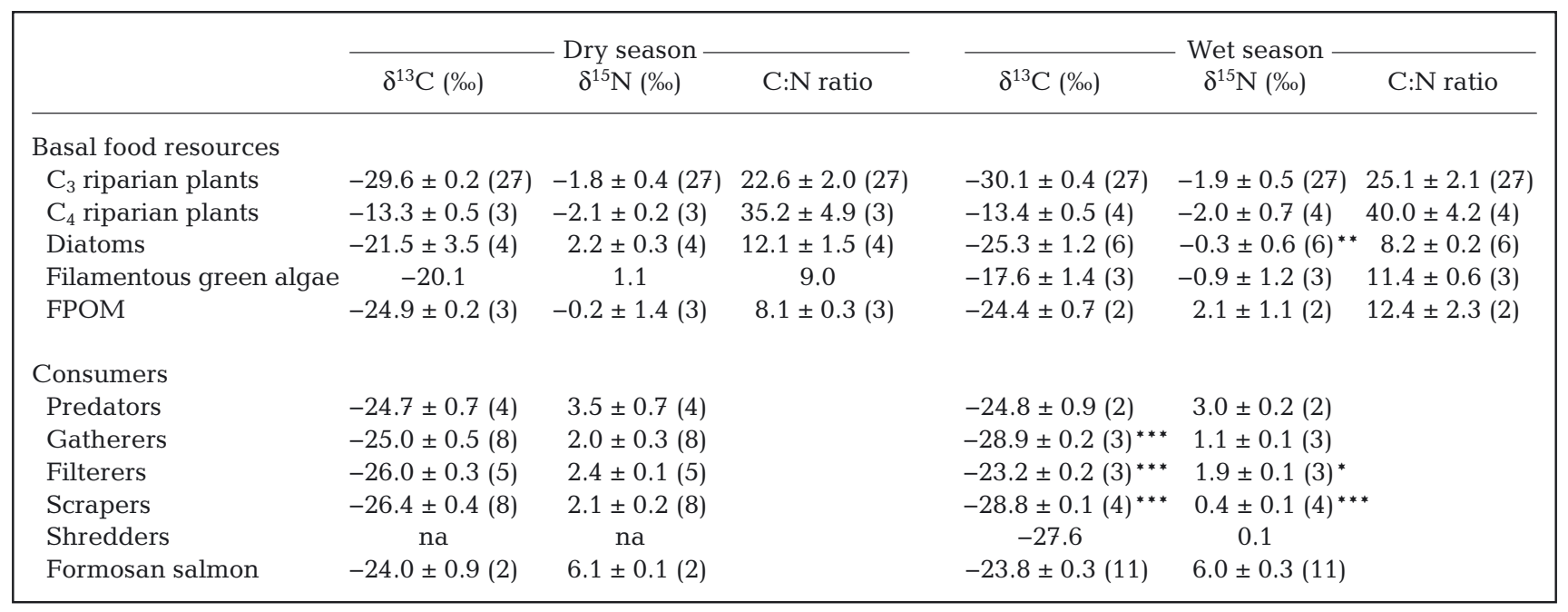


In the dry season, mean $\delta^{13} \mathrm{C}$ and $\delta^{15} \mathrm{~N}$ values of FPOM indicated that it was comprised of organic matter derived mainly from riparian $\mathrm{C}_{3}$ plants and diatoms (Fig. 2). However, $\delta^{15} \mathrm{~N}$ values of FPOM tended to be more enriched in the wet season than in the dry season $(p=0.10)$ and were relatively enriched over those of riparian plants and algae (Table 3).
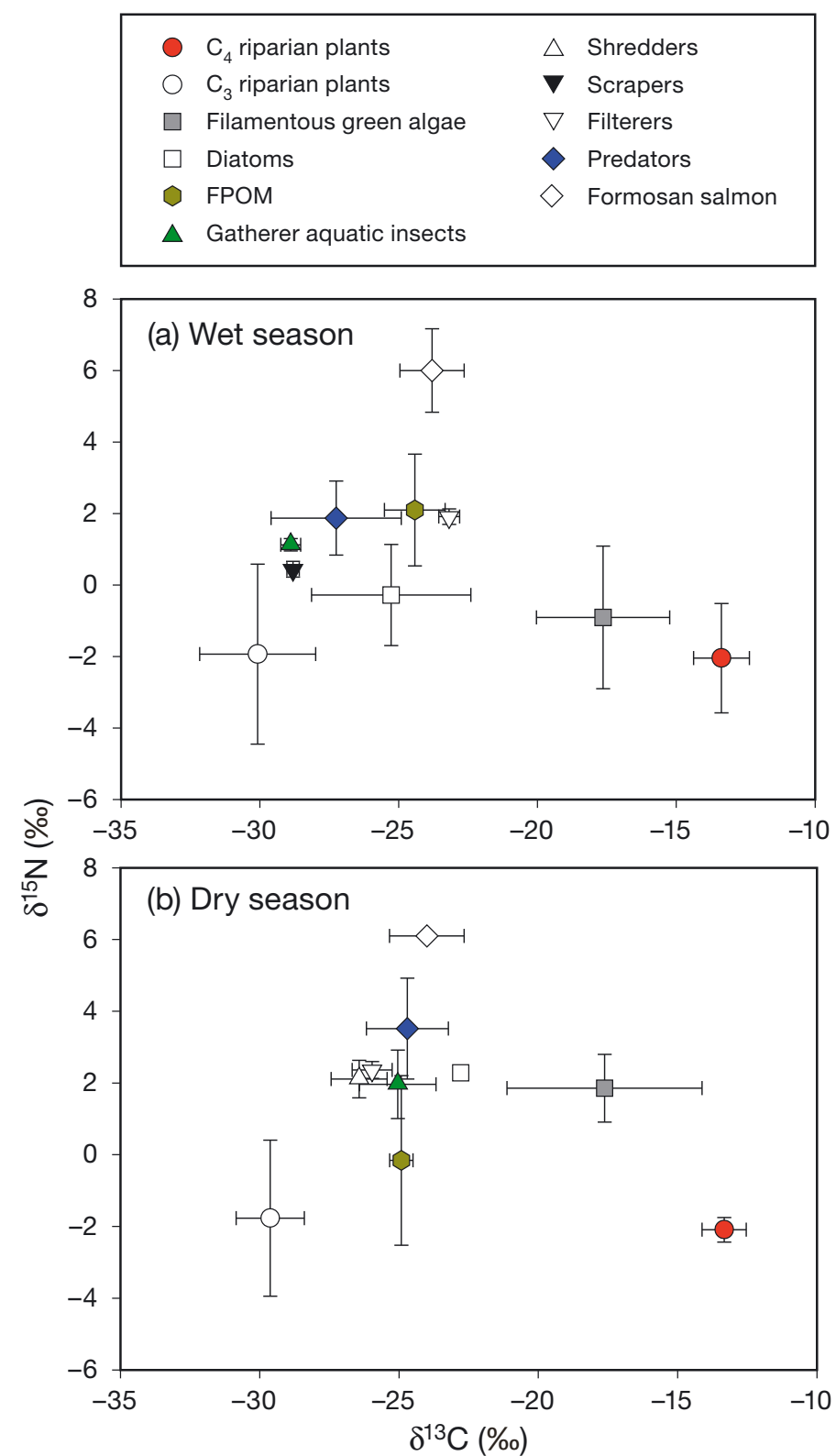

Fig. 2. $\delta^{15} \mathrm{~N}$ vs. $\delta^{13} \mathrm{C}$ (mean $\left.\pm 1 \mathrm{SE}, \mathrm{n}=1-27\right)$ of basal food resources and dominant consumers collected from Chichiawan Stream during the wet and dry seasons. FPOM: fine particulate organic matter

\section{Isotopic signatures of consumers}

In Chichiawan Stream, shredder aquatic insects were caught only in the wet season. Despite different diets, $\delta^{13} \mathrm{C}$ values of the 5 major feeding guilds of aquatic insects were similar, with mean values ranging from -23.2 to $-28.9 \%$ (Table 3 ). $\delta^{13} \mathrm{C}$ values of gatherers and scrapers were significantly more enriched in the dry season compared to the wet season. Conversely, $\delta^{13} \mathrm{C}$ values of filterers were significantly more enriched in the wet season.

In the dry season, variations in $\delta^{15} \mathrm{~N}$ values of gatherers, filterers, and scrapers were relatively small, and the mean values ranged from 2.0 to $2.4 \%$ (Table 3). $\delta^{15} \mathrm{~N}$ values of aquatic insects were significantly more enriched or tended to be so in the dry season. $\delta^{15} \mathrm{~N}$ values of predators were more enriched than those of other aquatic insects by 1.5 to $1.9 \%$.

$\delta^{13} \mathrm{C}$ and $\delta^{15} \mathrm{~N}$ values of Formosan salmon in Chichiawan Stream averaged -23.9 and $6.1 \%$, respectively (Table 3). Seasonal variations in $\delta^{13} \mathrm{C}$ and $\delta^{15} \mathrm{~N}$ values of the salmon were not significant. The results of SIA indicated that the trophic position of salmon is about 2 relative to the basal sources in both the dry and wet seasons (Fig. 2).

\section{Food sources of consumers}

Riparian $\mathrm{C}_{3}$ plants were the major food source for gatherers in the dry season and for filterers in the wet season (Table 4). The mean contributions of riparian $\mathrm{C}_{3}$ plants to gatherers and filterers reached 56 and $92 \%$, respectively. Diatoms were the major food source of scrapers in the wet season. The mean contribution of diatoms to scrapers reached $79 \%$. Riparian $\mathrm{C}_{4}$ plants contributed little to the food of the dominant consumers. FPOM was not found to contribute to any of the dominant consumers in Chichiawan Stream.

In the dry season, the food sources of predators were primarily scrapers and secondarily filterers (Table 5). Major food sources for Formosan salmon differed in the dry and wet seasons. In the dry season, the major food source for salmon was predators, but this shifted to filterers in the wet season.

\section{Food web structure}

The pedigree index was 0.71 for the trophic model of Chichiawan Stream, indicating a high-quality model, given that most inputs came from local, wellsampled, high-precision data. Trophic levels esti- 
Table 4. Percentage contribution (mean with the 1-99th percentile range in parentheses) of basal food sources to consumers calculated by IsoSource models for Chichiawan Stream during the dry and wet seasons

\begin{tabular}{|lcccc|}
\hline & $\begin{array}{c}\mathrm{C}_{3} \text { riparian } \\
\text { plants }\end{array}$ & $\begin{array}{c}\mathrm{C}_{4} \text { riparian } \\
\text { plants }\end{array}$ & $\begin{array}{c}\text { Diatoms } \\
\text { Cladophora } \\
\text { sp. }\end{array}$ \\
\hline $\begin{array}{l}\text { Dry season } \\
\text { Gatherers } \\
(\text { Baetis spp.) }\end{array}$ & $56(55-57)$ & $3(0-7)$ & $24(9-36)$ & $17(0-34)$ \\
$\begin{array}{l}\text { Wet season } \\
\text { Filterers } \\
(\text { Hydropsyche spp.) }\end{array}$ & $92(90-94)$ & $2(0-4)$ & $3(0-8)$ & $3(0-6)$ \\
$\begin{array}{c}\text { Scrapers } \\
(\text { Rhiehrogena ampla) }\end{array}$ & $0(0-1)$ & $1(0-2)$ & $79(77-80)$ & $20(18-22)$ \\
\hline
\end{tabular}

Table 5. Percentage contributions (mean with 1-99th percentile range in parentheses) of dominant primary consumers to secondary consumers calculated by IsoSource models for Chichiawan Stream during the dry and wet seasons

\begin{tabular}{|c|c|c|c|c|c|}
\hline & Collectors & Filterers & Scrapers & Shredders & Predators \\
\hline \multicolumn{6}{|l|}{ Dry season } \\
\hline $\begin{array}{l}\text { Predators } \\
\text { (Neoperla spp.) }\end{array}$ & $12(5-19)$ & $34(0-71)$ & $54(24-80)$ & & \\
\hline Formosan salmon & $20(0-56)$ & $14(0-36)$ & $12(0-34)$ & & $54(41-63)$ \\
\hline \multicolumn{6}{|l|}{ Wet season } \\
\hline Formosan salmon & $2(0-7)$ & $73(65-78)$ & $4(0-14)$ & $16(7-23)$ & $4(0-15)$ \\
\hline
\end{tabular}

mated by Ecopath from the weighted average of prey trophic levels varied from 1.00 for primary producers and detritus to 3.12 for birds (Fig. 3). The most prominent compartment in the stream was periphyton, comprising $92 \%$ of the system's total living biomass. Consumers accounted for only about $8 \%$ of the remaining total living biomass. The EE of periphyton was low (0.04), indicating that $96 \%$ of the production of periphyton was not immediately used and entered the detrital pool (Table 6). The trophic level of Formosan salmon was 2.97, and its biomass accounted for about $2.5 \%$ of the total living biomass. An omnivory index of only 0.40 indicated that the Formosan salmon mainly feeds on aquatic insects with a narrow range of trophic levels of 2.00 to 2.58 (Table 6). The EEs of these aquatic insects were generally far smaller than 0.95 , indicating that aquatic insects were not consumed in excess of their production in the stream. Birds were the only predators of Formosan salmon in the stream except for the salmon itself. The EE of Formosan salmon was only 0.05, which indicated that only $5 \%$ of its biomass was predated upon by birds or cannibalistically.

\section{Mixed trophic impacts}

The mixed trophic impacts analysis indicated that periphyton and detritus were the most influential compartments in the stream model (Fig. 4). An increase in periphyton biomass or detritus mass would have a great positive effect on aquatic insects, other invertebrates, fish, and birds, implying the significance of periphyton and detritus as food sources for consumers.

The mixed trophic impact analysis also demonstrated that increasing the biomass of scrapers would have a minor positive impact on predators and Formosan salmon. Conversely, increasing the biomass of salmon would have minor negative impacts on scrapers and filterers. The minor interactions can be attributed to the relatively small biomasses of salmon and aquatic insects in the stream (Table 1). Increasing the biomasses of birds and the shovelmouth minnow would have little impact on Formosan salmon. However, increasing the biomass of salmon would have a moderate negative impact on its biomass.

\section{Trophic flows}

The Lindeman trophic analysis aggregated compartmental throughputs of the 13 compartments in a simple food chain with 4 integer trophic levels (Fig. 5). The detritivory:herbivory (D:H) ratio of 0.94 indicated that the herbivory flow slightly exceeded detritivory flow in the stream. This suggests that primary production and detritus input are equally important as food sources for consumers in the stream. The contribution of net primary production to the stream by periphyton was $2205 \mathrm{~g} \mathrm{WW} \mathrm{m}^{-2} \mathrm{yr}^{-1}$ or $117 \mathrm{~g} \mathrm{C} \mathrm{m}^{-2} \mathrm{yr}^{-1}$, which far exceeded the $4.6 \mathrm{~g} \mathrm{WW}^{-2}$ $\mathrm{m}^{-2} \mathrm{yr}^{-1}\left(0.24 \mathrm{~g} \mathrm{C} \mathrm{m}^{-2} \mathrm{yr}^{-1}\right)$ from phytoplankton. The trophic efficiency was $4.2 \%$ for the combined flows from primary production and detritus for trophic level II (Fig. 5). Efficiency decreased at higher levels and was $0.3 \%$ for trophic level IV. The geometric mean of trophic efficiencies for the aggregated food chain from levels II to IV was calculated to be $1.5 \%$.

The TST of Chichiawan Stream was $4620 \mathrm{~g} \mathrm{WW}$ $\mathrm{m}^{-2} \mathrm{yr}^{-1}$ (Table 7). The difference between net prim- 


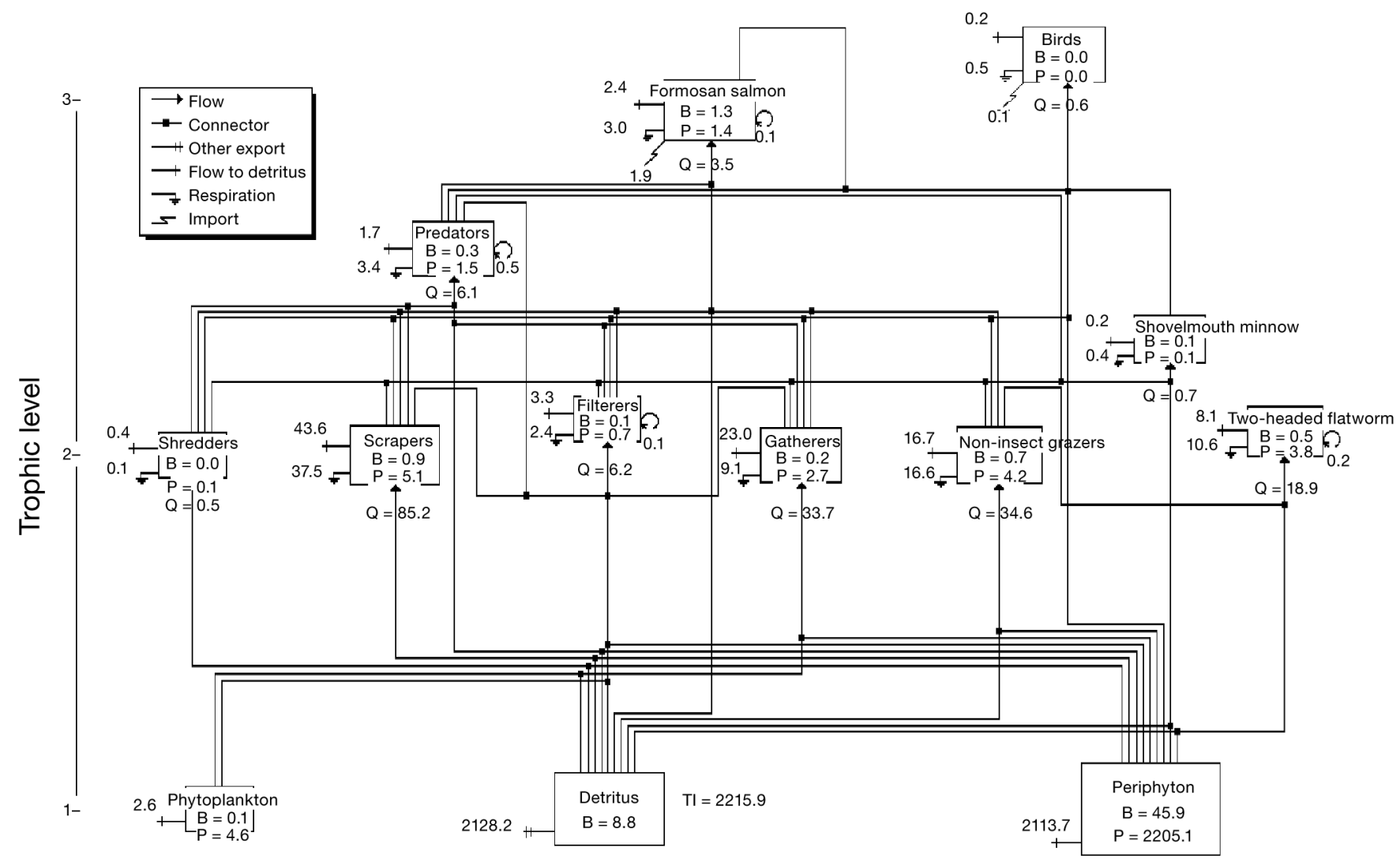

Fig. 3. Trophic model of Chichiawan Stream. Box size is proportional to the square root of the compartmental biomass (B) in $g$ wet weight (WW) $\mathrm{m}^{-2}$. Production (P), consumption (Q), sum of all flows into detritus (TI), and other flows are in $\mathrm{g} W W \mathrm{~m}^{-2} \mathrm{yr}^{-1}$. Circular arrows to the right of some boxes indicate flow back to the compartment itself

ary production (NPP) and total R (i.e. net system production) in the stream was $2126 \mathrm{~g} \mathrm{WW} \mathrm{m}^{-2} \mathrm{yr}^{-1}(113 \mathrm{~g}$ $\mathrm{C} \mathrm{m}^{-2} \mathrm{yr}^{-1}$ ). The NPP:R ratio of 26.4 indicated that the stream was highly autotrophic, which implies that much more organic matter was being produced than was being consumed in the stream. The cycle analysis showed that all cycled flows accounted for only $1.10 \%$ of the TST (i.e. FCI).

\section{DISCUSSION}

Stream food webs generally rely on 2 major food sources: autochthonous primary production originating from the stream itself, and allochthonous organic matter from the surrounding landscape transferred to the stream as leaf litter, woody debris, and dissolved organic carbon. Finlay (2001) found that algal production was a major diet of scrapers at all headwater sites where scrapers were present, and of gatherers and filterers at some sites. He indicated that in streams with a watershed area of $\geq 10 \mathrm{~km}^{2}, \delta^{13} \mathrm{C}$ values of consumers were more related to algal than ter- restrial carbon sources for all groups except shredders, even though most organic matter in the streams was terrestrially derived. In tropical headwater streams in Hong Kong, Lau et al. (2009) also found that autochthonous sources are possibly more important than terrestrial detritus inputs to secondary production. However, Hoeinghaus et al. (2007) indicated that direct riparian inputs were more important than algal production for higher-gradient stream food webs. In the high-altitude subtropical Chichiawan Stream, with a watershed area of $76 \mathrm{~km}^{2}$ and a high gradient of $13 \%$, we found that algal production contributed most to the food sources of scrapers. However, the present study also demonstrated that allochthonous sources derived from the riparian forest contributed most to the food sources of gatherers and filterers in the stream. Lindeman trophic analysis of the stream model showed that herbivory and detritivory flows were quantitatively equally important as food sources for consumers in the stream. In an adjacent headwater, the food web was also fuelled by both autochthonous and allochthonous resources (Huang et al. 2007). 


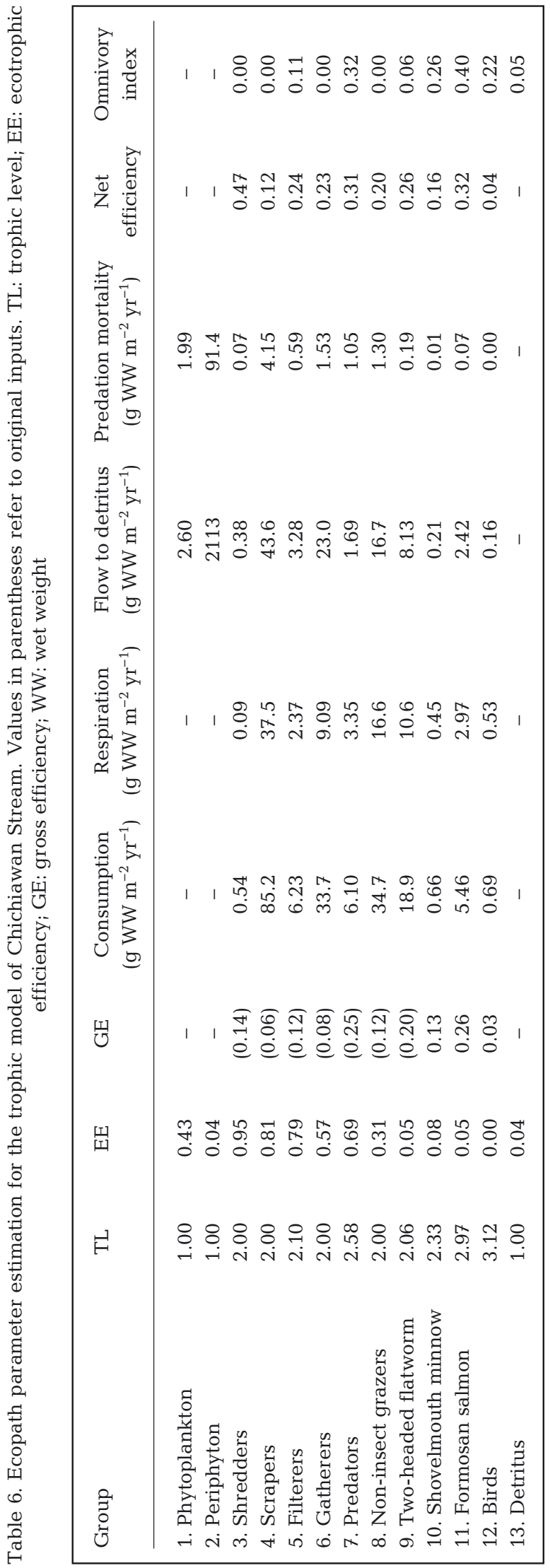

Our results further demonstrated that the food sources of filterers and gatherers in Chichiawan Stream were primarily riparian $\mathrm{C}_{3}$ plants in both the dry and wet seasons. These feeding guilds of aquatic insects combined with predators were the major food sources of Formosan salmon in this stream. Our results suggest a close terrestrial-aquatic linkage that highlights the function of riparian plants in transferring energy through trophic cascades of this subtropical headwater stream. It is clear that the riparian zone along Chichiawan Stream should be well-vegetated in order to provide food sources for aquatic insects on which the Formosan salmon feeds.

This study also demonstrated that riparian $\mathrm{C}_{3}$ plants were much more important than $\mathrm{C}_{4}$ plants in contributing to the food sources of dominant consumers in the stream. The contribution of riparian $\mathrm{C}_{4}$ plants was negligible. One possibility is that the $\mathrm{C}: \mathrm{N}$ molar ratios of $\mathrm{C}_{3}$ plant samples were lower than those of $\mathrm{C}_{4}$ plant samples (Table 3), as these were indicative of more labile samples. The other possibility is that $\mathrm{C}_{4}$ plants are the source of only a small fraction of the terrestrial detritus reaching the stream. Tsai et al. (2010) surveyed land uses along Chichiawan Stream by digitizing aerial photographs in a geographic information system and found that the percentage cover of riparian $\mathrm{C}_{4}$ plants in the Wuling basin was small (about $0.1 \%$ ).

The lower reach of Chichiawan Stream is moderately influenced by agriculture ( $\mathrm{Yu} \&$ Lin 2009). In the dry season, $\mathrm{NO}_{3}^{-}$concentrations of the stream water were higher and $\delta^{15} \mathrm{~N}$ values of $\mathrm{NO}_{3}{ }^{-}$were more enriched (Peng et al. 2012). Therefore, $\delta^{15} \mathrm{~N}$ values of both green algae and diatoms, but not terrestrial plants, were more enriched in the dry than in the wet season. The relatively depleted $\delta^{15} \mathrm{~N}$ values in the wet season can be attributed to the fact that a high proportion of $\mathrm{NO}_{3}{ }^{-}$flowing into the stream water was derived from the large amount of rainfall, the $\delta^{15} \mathrm{~N}$ values of which were about $0 \%$ (Kendall \& Caldwell 1998). Conversely, in the dry season, instead of rainfall, $\mathrm{NO}_{3}{ }^{-}$flowing into the stream was leached mainly from nearby soils, the $\delta^{15} \mathrm{~N}$ values of which were about 2 to $5 \%$ (Kendall \& Caldwell 1998).

Filamentous green algae were observed more frequently in open-canopy sections of the Chichiawan Stream that are subject to high $\mathrm{NO}_{3}{ }^{-}$concentrations (Yu \& Lin 2009). Despite this, SIA demonstrated that filamentous green algae were not the major food source of the dominant aquatic insects in the stream, indicating that a relatively low proportion of the macroalgae was being consumed. If agricultural 


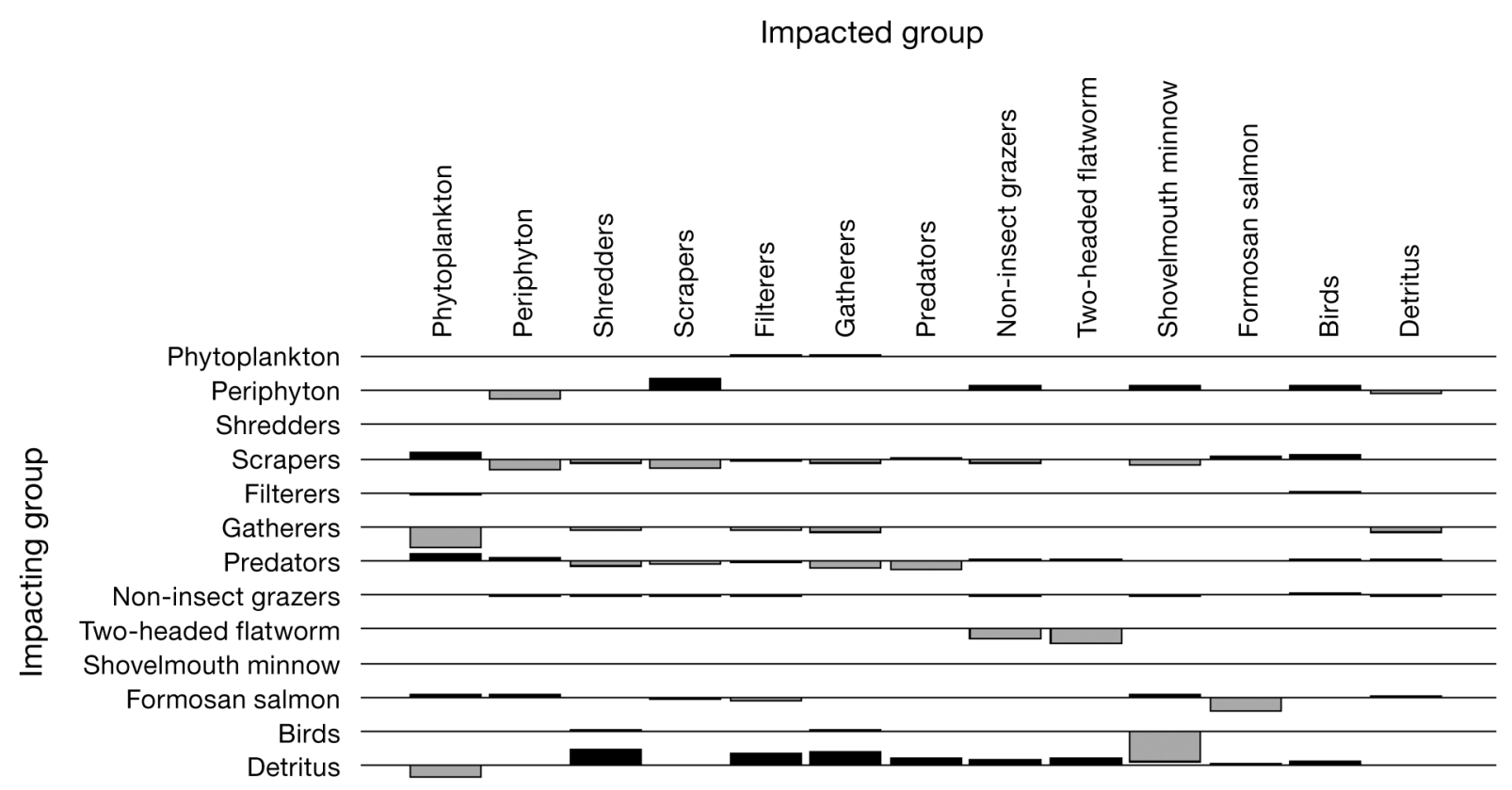

Fig. 4. Mixed trophic impacts of the trophic model of Chichiawan Stream, showing direct and indirect impacts that an increase in the biomass of a compartment on the left of the histograms would have on compartments positioned above it. Black (grey) bars pointing upwards (downwards) indicate positive (negative) impacts. Impacts are relative, not absolute, but are comparable between histograms

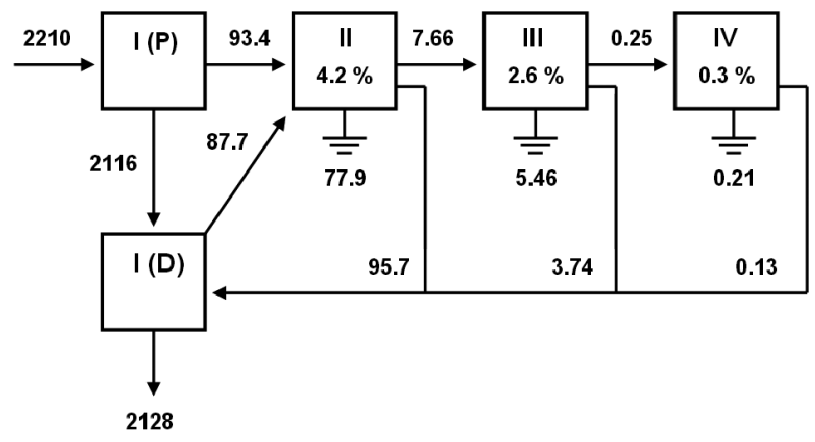

Fig. 5. Lindeman trophic analysis of the trophic model of Chichiawan Stream. The compartmental throughputs (g wet weight $\mathrm{m}^{-2} \mathrm{yr}^{-1}$ ) of the 13 compartments were aggregated into a concatenated chain of transfers through 4 integer trophic levels. Flows from primary producers (P) and from detritus (D) and flows out of the bottoms represent respiration. Trophic efficiencies (\%) of the transfer from 1 aggregated trophic level to the next were calculated as the fraction of the input of organic matter to a given level that was transferred to the next higher level. Trophic level I: producers; II: herbivores or primary consumers; III: carnivores or secondary consumers; IV: top carnivores or tertiary consumers

activity continues as usual in the stream, more filamentous green algae will likely accumulate on the sediments and cause the water quality to deteriorate.

Using SIA, we discovered a seasonal shift in the diet of Formosan salmon in Chichiawan Stream. Predators were the major food sources during the dry season, but this shifted to filterers in the wet season, when these insects comprised $73 \%$ of the food sources. Lin et al. (2006) found that in the wet season, scrapers had the highest relative abundance among feeding guilds of aquatic insects, followed by filterers. In the dry season, however, the highest relative abundance of feeding guilds of aquatic insects was of scrapers, followed by gatherers and predators. Although small-sized scrapers were the most abundant feeding guild of aquatic insects in both seasons in Chichiawan Stream, they were not the primary food sources for Formosan salmon. The seasonal diet shift of salmon from predators in the dry season to filterers in the wet season may be due to the large rainfall amounts which often remove a high proportion of large-sized predators in the wet season (Chiu et al. 2008).

The trophic model of Chichiawan Stream showed that the biomass of aquatic insects available for the Formosan salmon was much greater than the amount it consumed, which suggests that the fish are generally not constrained by food sources. This can be reflected by the mixed trophic impacts analysis, which demonstrated that increasing the biomass of aquatic insects would have a minor impact on Formosan salmon. Fishing for Formosan salmon is prohibited by the Taiwanese government, and the mixed trophic impacts analysis demonstrated low 
Table 7. Comparisons of ecosystem attributes between Chichiawan Stream and mountain streams in temperate regions. NPP: total net primary production; NSP: net system production; R: total respiration; B: total biomass; TST: total system throughput; TE: trophic transfer efficiency; WW: wet weight; na: data not available

\begin{tabular}{|c|c|c|c|}
\hline Study site & $\begin{array}{l}\text { Chichiawan } \\
\text { Stream, Taiwan }\end{array}$ & $\begin{array}{l}\text { Steina Stream, } \\
\text { Germany }^{\mathrm{a}}\end{array}$ & $\begin{array}{l}\text { Alte Schwentine } \\
\text { River, Germany }^{\mathrm{b}}\end{array}$ \\
\hline 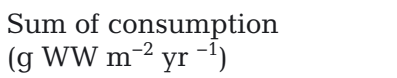 & 192 & 6489 & 13239 \\
\hline $\begin{array}{l}\text { Sum of exports } \\
\left(\mathrm{g} W W \mathrm{~m}^{-2} \mathrm{yr}^{-1}\right)\end{array}$ & 2128 & 9.1 & 14.7 \\
\hline 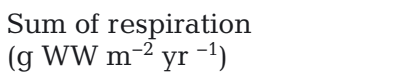 & 84 & 3441 & 3455 \\
\hline 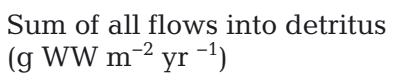 & 2216 & 9764 & 12013 \\
\hline TST $\left(\mathrm{g} \mathrm{WW} \mathrm{m}^{-2} \mathrm{yr}^{-1}\right)$ & 4620 & 19703 & 28722 \\
\hline NPP (g WW m $\left.{ }^{-2} \mathrm{yr}^{-1}\right)$ & 2210 & 857 & 2896 \\
\hline NSP $\left(g\right.$ WW m ${ }^{-2} \mathrm{yr}^{-1}$ ) & 2126 & 2430 & 560 \\
\hline NPP:R & 26.4 & 0.25 & 0.84 \\
\hline NPP:B & 44 & 5.48 & 0.91 \\
\hline B:TST & 0.01 & 0.01 & 0.11 \\
\hline $\begin{array}{l}\text { Total biomass (B, no detritus) } \\
\text { (g WW m }{ }^{-2} \mathrm{yr}^{-1} \text { ) }\end{array}$ & 50 & 156 & 168 \\
\hline $\mathrm{TE}(\%)$ & 1.5 & $2.6-7.1$ & $0.2-6.0$ \\
\hline Finn's cycling index (\%) & 1.1 & 25.1 & na \\
\hline
\end{tabular}

was comparable to the reported values of the 2 temperate streams. This indicates that consumer biomass is relatively low in Chichiawan Stream, which is reflected in the extremely high NPP:R and NPP:B ratios and low B compared to reported values from the 2 temperate streams. Although Lindeman trophic analysis showed that herbivory and detritivory flows were quantitatively equally important as food sources for consumers in Chichiawan Stream, the relatively lower FCI value indicated that a lower proportion of organic matter is recycled through detrital pathways by consumers (Table 7). Therefore, the geometric mean transfer efficiency of Chichiawan Stream is lower than those of the 2 temperate streams.

Continental islands in the tropics/ subtropics of the western Pacific are characterized by mountainous watersheds, high precipitation, and high water runoff (Smith et al. 2003). Chichiawan Stream fits

predation pressure by birds on the fish. Habitat uses by salmon and the sympatric shovelmouth minnow were distinct. Hsu et al. (2010) discovered that Formosan salmon used habitats which were subject to lower temperatures and were distributed in reaches at higher elevations than those of shovelmouth minnow. The diet composition matrix also demonstrated that the Formosan salmon is insectivorous, whereas the shovelmouth minnow relies heavily on algae. Our results indicate that hydrological conditions and substratum composition might be more important than predation and competition in influencing the abundance of Formosan salmon in Chichiawan Stream.

Trophic modelling is a tool for comparative analyses of ecosystems (Christian et al. 2005) that may be helpful in characterizing the structure and functioning of Chichiawan Stream. However, few researchers have attempted to construct trophic models for streams using the Ecopath approach, with the exception of 2 mountain streams in Germany (Poepperl 2003, Meyer \& Poepperl 2004). The TST of Chichiawan Stream was remarkably low in terms of the flow per unit area compared to the 2 temperate streams (Table 7), due to the low consumption and respiration of consumers in the stream. However, the NPP of Chichiawan Stream these characteristics, as it has relatively short, straight, steep channels in a comparatively small, narrow basin. The rapid current velocity and changing flow regime in the stream have likely depressed consumer biomass and influenced the trophic transfer of organic matter in the food web (Chang et al. 2012). Our model reveals that the relatively low biomass of consumers was insufficient to consume excess growth of macroalgae that resulted from nutrient loading. Thus, agricultural activity in particular makes Chichiawan Stream even more vulnerable. To conserve the Formosan salmon, the first priority is agricultural runoff control and maintaining a wellvegetated riparian zone. Riparian vegetation may not only provide food sources for salmon in the stream, but may also protect stream water quality by trapping debris and sediments and filtering pollutants through physical and biological processes (Seavy et al. 2009). Moreover, riparian vegetation may lower water temperature, promote water infiltration, and reduce runoff to the stream as more precipitation falls as rain (Brauman et al. 2007). These would make Chichiawan Stream more resistant against rising temperature, extreme floods, and altered surface flows anticipated from climate change. 
Acknowledgements. This study was financially supported by Shei-Pa National Park Headquarters, Miaoli County, Taiwan. We thank M. L. Liao for field assistance and H. Y. Chang for discussions and comments on this manuscript and for assistance with the use of IsoSource.

\section{LITERATURE CITED}

Altig R, McDearman W (1975) Percent assimilation and clearance times of five anuran tadpoles. Herpetologica 31:67-69

- Benke AC, Jacobi DI (1994) Production dynamics and resource utilization of snag-dwelling mayflies in a blackwater river. Ecology 75:1219-1232

Benke AC, Van Arsdall TC Jr, Gillespie DM, Parrish FK (1984) Invertebrate productivity in a subtropical blackwater river: the importance of habitat and life history. Ecol Monogr 54:25-63

> Benke AC, Wallace JB, Harrison JW, Koebel JW (2001) Food web quantification using secondary production analysis: predaceous invertebrates of the snag habitat in a subtropical river. Freshw Biol 46:329-346

Boyero L, Ramírez A, Dudgeon D, Pearson RG (2009) Are tropical streams really different? J N Am Benthol Soc 28: 397-403

> Brauman KA, Daily GC, Duarte TK, Mooney HA (2007) The nature and value of ecosystem services: an overview highlighting hydrologic services. Annu Rev Environ Resour 32:67-98

- Carlisle DM, Clements WH (2003) Growth and secondary production of aquatic insects along a gradient of $\mathrm{Zn}$ contamination in Rocky Mountain streams. J N Am Benthol Soc 22:582-597

> Chang HH, Wu SH, Shao KT, Kao WY and others (2012) Longitudinal variation in food sources and their use by aquatic fauna along the length of a subtropical river in Taiwan. Freshw Biol 57:1839-1853

Chiu MC, Kuo MH, Sun YH, Hong SY, Kuo HC (2008) Effects of flooding on avian top-predators and their invertebrate prey in a monsoonal Taiwan stream. Freshw Biol 53:1335-1344

Christensen V, Walters CJ, Pauly D (2004) Ecopath with Ecosim: a user's guide. University of British Columbia, Fisheries Centre, Vancouver

Christian RR, Baird D, Luczkovich J, Johnson JC, Scharler UM, Ulanowicz RE (2005) Role of network analysis in comparative ecosystem ecology of estuaries. In: Belgrano A, Scharler UM, Dunne J, Ulanowicz RE (eds) Aquatic food webs. Oxford University Press, Oxford, p 25-40

Chung LC, Lin HJ, Yo SP, Tzeng CS, Yang CH (2007) A stage dependent population matrix model for the Formosan landlocked salmon (Oncorhynchus masou formosanus) in Taiwan. Raffles Bull Zool 14(Suppl):151-160

Chung LC, Lin HJ, Yo SP, Tzeng CS, Yeh CH, Yang CH (2008) Relationship between the Formosan landlocked salmon Oncorhynchus masou formosanus population and the physical substrate of its habitat after partial dam removal from Kaoshan Stream, Taiwan. Zool Stud 47: 25-36

Crocker D, Hart A, Gurney J, McCoy C (2002) Methods for estimating daily food intake of wild birds and mammals. Final Report of Project PN0908. Department for Environment, Food and Rural Affairs, Sand Hutton

> Delong MD, Thorp JH (2006) Significance of instream auto- trophs in the trophic dynamics of the Upper Mississippi River. Oecologia 147:76-85

DeNiro MJ, Epstein S (1978) Influence of diet on the distribution of carbon isotopes in animals. Geochim Cosmochim Acta 42:495-506

Dermott R (1981) Ingestion rate of the burrowing mayfly Hexagenia limbata as determined with ${ }^{14} \mathrm{C}$. Hydrobiologia 83:499-503

> Dudgeon D, Cheung FKW, Mantel SK (2010) Foodweb structure in small streams: Do we need different models for the tropics? J N Am Benthol Soc 29:395-412

Field JG, Wulff F, Mann KH (1989) The need to analyze ecological networks. In: Wulff F, Field JG, Mann KH (eds) Network analysis in marine ecology: methods and applications. Springer-Verlag, New York, NY, p 3-12

Finlay JC (2001) Stable-carbon-isotope ratios of river biota: implications for energy flow in lotic food webs. Ecology 82:1052-1064

Froese R, Pauly D (2007) FishBase. Available at www.fishbase.org (accessed in February 2007)

Frost PC, Cherrier CT, Larson JH, Bridgham S, Lamberti GA (2007) Effects of dissolved organic matter and ultraviolet radiation on the accrual, stoichiometry and algal taxonomy of stream periphyton. Freshw Biol 52:319-330

Funtowicz SO, Ravetz JR (1990) Uncertainty and quality in science for policy. Kluwer, Dordrecht

Gonfiantini R, Stichler W, Rozanski K (1995) Standards and intercomparison materials distributed by the international atomic energy agency for stable isotope measurements. IAEA-TECDOC-825. IAEA, Vienna, p 13-29

Grafius E, Anderson NH (1980) Population dynamics and role of two species of Lepidostoma (Trichoptera: Lepidostomatidae) in an Oregon coniferous forest stream. Ecology 61:808-816

Hershey AE, Peterson BJ (1996) Stream food webs. In: Hauer FR, Lamberti GA (eds) Methods in stream ecology. Academic Press, San Diego, CA, p 511-530

$>$ Hoeinghaus DJ, Winemiller KO, Agostinho AA (2007) Landscape-scale hydrologic characteristics differentiate patterns of carbon flow in large-river food webs. Ecosystems 10:1019-1033

> Hsu CB, Tzeng CS, Yeh CH, Kuan WH, Kuo MH, Lin HJ (2010) Habitat use by the Formosan landlocked salmon Oncorhynchus masou formosanus. Aquat Biol 10: 227-239

Huang IY, Lin YS, Chen CP, Hsieh HL (2007) Food web structure of a subtropical headwater stream. Mar Freshw Res 58:596-607

Hunter RD (1975) Growth, fecundity, and bioenergetics in three populations of Lymnaea palustris in upstate New York. Ecology 56:50-63

Hyslop EL (1980) Stomach contents analysis - a review of methods and their application. J Fish Biol 17:411-429

Iversen TM (1988) Secondary production and trophic relationships in a spring invertebrate community. Limnol Oceanogr 33:582-592

Jassby AD, Platt T (1976) Mathematical formulation of the relationship between photosynthesis and light for phytoplankton. Limnol Oceanogr 21:540-547

Kawai T, Tanida K (2005) Aquatic insects of Japan: manual with keys and illustrations. Tokai University Press, Hadano

Kay JJ, Graham LA, Ulanowicz RE (1989) A detailed guide to network analysis. In: Wulff F, Field JG, Mann KG (eds) Network analysis in marine ecology: method and 
applications. Coastal and Estuarine Studies Series. Springer-Verlag, Heidelberg, p 15-63

Kendall C, Caldwell EA (1998) Fundamentals of isotope geochemistry. In: Kendall C, McDonnell JJ (eds) Isotope tracers in catchment hydrology. Elsevier, Amsterdam, p 51-86

Kottelat M (1996) Oncorhynchus formosanus. IUCN red list of threatened species. Available at www.iucnredlist.org (accessed 25 Dec 2006)

Lan CH (2005) Studies on the population growth dynamics of the Formosan landlocked salmon Oncorhynchus masou formosanus with special reference on individual tagged fish. MSc thesis, University of National Taiwan Ocean, Keelung (in Chinese)

Lau DCP, Leung KMY, Dudgeon D (2009) Are autochthonous foods more important than allochthonous resources to benthic consumers in tropical headwater streams? J N Am Benthol Soc 28:426-439

Lin HJ, Wang TC, Su HM, Hung JJ (2005) Relative importance of phytoplankton and periphyton on oyster-culture pens in a eutrophic tropical lagoon. Aquaculture 243: 279-290

Lin HJ, Yeh CH, Kuan WH, Peng TR and others (2006) Longterm ecological monitoring and ecosystem modeling in the Wuling area. Tech Rep. Shei-Pa National Park Administration, Taichung (in Chinese)

Lin YS, Tsao SS, Chang KH (1990) Population and distribution of the Formosan landlocked salmon (Oncorhynchus masou formosanus) in Chichiawan Stream. Bull Inst Zool Acad Sinica 29:73-85

Madsen M (1992) Food selection by freshwater snails in the Gezira irrigation canals, Sudan. Hydrobiologia 228: 203-217

McCutchan JH Jr, Lewis WM, Kendal C, McGrath CC (2003) Variation in trophic shift for stable isotope ratios of carbon, nitrogen, and sulfur. Oikos 102:378-390

Merritt RW, Cummins KW (1996) An introduction to the aquatic insects of North America. Kendall/Hunt Publishing Company, Dubuque, IA

> Meyer EI, Poepperl R (2004) Assessing food-web structure, matter fluxes, and system attributes of a Central European mountain stream by performing mass-balanced network analysis. Can J Fish Aquat Sci 61:1565-1581

Meyercordt J, Meyer-Reil LA (1999) Primary production of benthic microalgae in two shallow coastal lagoons of different trophic status in the southern Baltic Sea. Mar Ecol Prog Ser 178:179-191

Minagawa M, Wada E (1984) Stepwise enrichment of ${ }^{15} \mathrm{~N}$ along food chains: further evidence and the relation between $\delta^{15} \mathrm{~N}$ and animal age. Geochim Cosmochim Acta 48:1135-1140

Opitz S (1996) Trophic interactions in Caribbean coral reefs. ICLARM Tech Rep 43. International Center for Living

Editorial responsibility: Asbjørn Vøllestad, Oslo, Norway
Aquatic Resources Management, Makati City

Oshima M (1955) Masu salmon, Oncorhynchus masou (Brevoort), and Biwa salmon, Oncorhynchus rhodurus (Jordan and McGregor). Nireshobo, Tokyo (in Japanese)

> Palomares MLD, Pauly D (1989) A multiple regression model for predicting the food consumption of marine fish populations. Aust J Mar Freshw Res 40:259-273

Peng TR, Lin HJ, Wang CH, Liu TS, Kao SJ (2012) Pollution and variation of stream nitrate in a protected highmountain watershed of Central Taiwan: evidence from nitrate concentration and nitrogen and oxygen isotope compositions. Environ Monit Assess 184:4985-4998

Phillips DL, Gregg JW (2003) Source partitioning using stable isotopes: coping with too many sources. Oecologia 136:261-269

Poepperl R (2003) A quantitative food web model for the macroinvertebrate community of a northern German lowland stream. Int Rev Hydrobiol 88:433-452

Reynoldson TB (1975) Odd overlap of lake-dwelling triclads in the field. J Anim Ecol 44:245-250

Seavy NE, Gardali T, Golet GH, Griggs FT and others (2009) Why climate change makes riparian restoration more important than ever: recommendations for practice and research. Ecol Res 27:330-338

Smith GC, Covich AP, Brasher AMD (2003) An ecological perspective on the biodiversity of tropical island streams. Bioscience 53:1048-1051

Su HM, Lin HJ, Hung JJ (2004) Effects of tidal flushing on phytoplankton in a eutrophic tropical lagoon in Taiwan. Estuar Coast Shelf Sci 61:739-750

Sun YH (2004) The study of predation by birds on the Formosan landlocked salmon. II. Shei-Pa National Park Administration, Taichung (in Chinese)

Tsai ST, Shu HS, Lu KC (2010) Composition and structure of riparian vegetation in the Cijiawan Stream. Q J For Res 32:19-38

Tsao EHS, Lin YS, Behnke RJ, Bergersen EP (1998) Microhabitat use by Formosan landlocked salmon, Oncorhynchus masou formosanus. Zool Stud 37:269-281

Ueno M (1937) On the food habits and parasites of the masu salmon of the Taiko River, Taiwan. Nat Hist Mag 27: 153-159 (in Japanese)

Ulanowicz RE, Puccia CJ (1990) Mixed trophic impacts in ecosystems. Coenoses 5:7-16

- Welch HE (1968) Relationships between assimilation efficiencies and growth efficiencies for aquatic consumers. Ecology 49:755-759

- Wiens JA, Nussbaum RA (1975) Model estimation of energy flow in northwestern coniferous forest bird communities. Ecology 56:547-561

Yu SF, Lin HJ (2009) Effects of agriculture on the abundance and community structure of epilithic algae in mountain streams of subtropical Taiwan. Bot Stud 50:73-87

Submitted: March 7, 2012; Accepted: October 24, 2012

Proofs received from author(s): December 6, 2012 